\title{
DRIVER MUTATIONS IN MELANOMA
}

\author{
SNJEŽANA RAMIĆ and MELITA PERIĆ BALJA \\ Department of Oncological Pathology, ‘Ljudevit Jurak' University Department of Pathology, \\ Sestre milosrdnice University Hospital Center, Ilica 197, Zagreb, Croatia
}

\begin{abstract}
Summary
In this review, we present the findings from the literature on several new molecules that can be targeted in the melanoma treatment process, especially metastatic melanoma, since five-year survival rates are below 20\%. Recently, melanoma has been defined by mutations that occur in oncogenes and lead to melanomagenesis. A mutation in BRAF gene selects the patients for targeting therapy with BRAF inhibitors. Although BRAF inhibitor therapy is associated with clinical benefit, the majority of patients with the BRAFV600-mutated metastatic melanoma develop resistance, usually within the first year. Clinically significant discrepancy in BRAF status, between primary melanoma and its metastasis were detected in about $15 \%$ of cases. There are no specific recommendations on BRAF re-testing, but might be clinically relevant to repeat testing on recent metastatic sites in cases of previous BRAF wild type results.
\end{abstract}

KEY WORDS: metastatic melanoma, BRAF, p53, signaling pathway, mutations

\section{Sažetak}

\section{MUTACIJE KOD MELANOMA U PROGRESIJI}

U ovom preglednom radu, predstavljena su saznanja iz literature o nekoliko novih molekula na koje može biti usmjeren razvoj ciljane terapije u procesu liječenja melanoma, osobito metastatskog, gdje je petogodišnje preživljenje manje od 20\%. Melanomi su sve češće definirani mutacijama u onkogenima koje dovode do maligne trasnformacije. Mutacije BRAF gena određuju bolesnike za ciljanu terapiju BRAF inhibitorima. Iako bolesnici imaju kliničku korist od terapije, većina bolesnika s BRAFV600 mutiranim metastatskim melanomom postanu rezistentni unutar godinu dana. Klinički značajne razlike u BRAF statusu između primarnog melanoma i metastaza, javljaju se u oko 15\% slučajeva. Nema specifičnih preporuka za ponovno BRAF testiranje, ali može biti klinički značajno ponoviti testiranje na novonastalim metastazama, u slučajevima prethodnih BRAF rezultata divljeg tipa.

KLJUČNE RIJEČI: metastatski melanom, BRAF, p53, signalni put, mutacije

\section{INTRODUCTION}

Melanoma is a malignant tumor of melanocytes (MM). Melanoma development correlates with the DNA damage caused by ultraviolet light (UV). In recent years the melanoma rate is in- creasing, probably due to increased unprotected exposure to UV radiation from either the sun or a variety of tanning devices. Apart sun exposure, older age, Caucasian raise or pre-existing moles, some genetic disorders increase the risk of melanoma (1). 
Melanoma early stage, histologically is referred as the radial growth phase of melanocytes, spreading in the papillary dermis in depth less than $1 \mathrm{~mm}$ (Clark 2, Breslow 1). Deeper invasion of melanoma in the papillary dermis, referring as vertical growth phase, enables melanoma reaching the blood vessels and spreading to other parts of the body. Early stage melanoma often is cured surgically; otherwise, the treatment of choice is traditional cytotoxic chemotherapy, targeted therapies, and immune-based therapies (2). Metastatic melanoma (MM) treatment, with 5-year survival rate less than $20 \%$ due to resistance to standard chemotherapy, still remains a challenge (2). Although, MM is classified according to histology (Clark, Breslow, TNM), recently is defined by mutations that occur in oncogenes and lead to melanomagenesis.

\section{Physiological condition}

The melanocytes physiological role is producing the pigment melanin that protects the body from the sunlight damaging effect. UV light damages the DNA directly and indirectly. Direct damage occurs when DNA absorbs UV photons, resulting in thymine-thymine dimers while indirect damage occurs via production of reactive oxygen radicals that can cause single-strand DNA breaks, or oxidize the nucleobases $(3,4)$. If unrepared, aforementioned damages can cause inaccurate synthesis during DNA replication or repair, leading to mutations (4).

Sunlight damages kerationcytes positioned in the upper layers of skin, activating the DNA damage repair mechanism via p53 protein and also induce signalling towards the melanocytes to produce the melanin (3). Short-term sunlight exposure results in changed distribution of melanin granules (melanosomes) from the melanocytes to keratinocytes. Long-term tanning increase pigmentation by melanocytes modulation through keratinocytes signaling $(1,3)$. Keratinocytes excrete alpha-melanocyte stimulating hormone (aMSH) which binds to the melanocortin-1 receptor $(\mathrm{MC1R})$ on the surface of the melanocyte, activates microphthalmia associated transcription factor (MITF) and induces the production of melanin $(4,5)$. On chronically sun-damaged skin, keratinocytes modulates melanocytes over c-KIT receptor signaling and activation of the RAS-RAF-

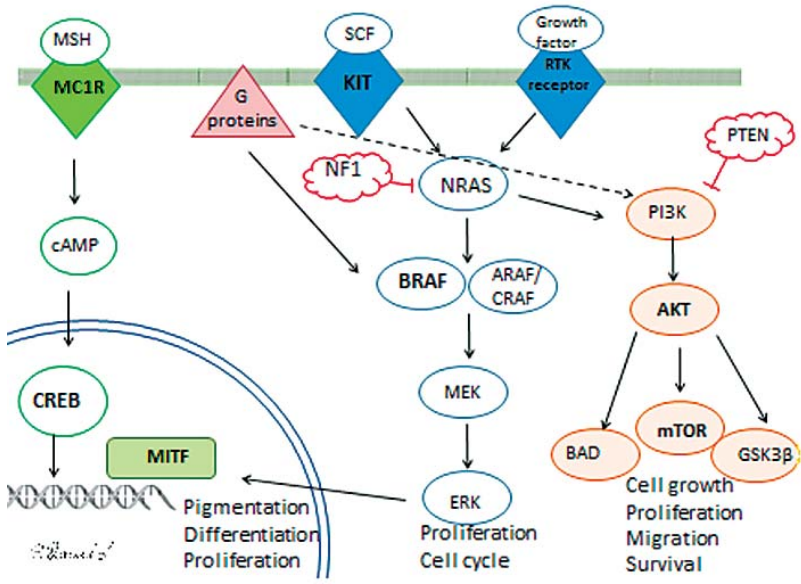

Figure 1. Schematic diagram of important signaling pathways in melanoma. Signaling through MC1R receptor activates melanin synthesis, c-KIT signaling is essential for melanocyte development and MAPK signaling promotes cell growth and survival (Ramić, S.).

MEK-ERK pathway (MAPK), which is crucial in melanocyte development and proliferation. RAS proteins can activate the MAPK pathway (involved in cell differentiation and proliferation) or the PI3K/AKT/mTOR pathway (involved in cell survival) $(4,5)$. Somatic mutations in these pathways are the main driver of malignancy.

\section{Mutation events}

A mutation of tumor suppressor gene TP53 is one of the earliest events in melanocytes caused by UV radiation, resulting in non-functional p53 protein, detected in over $40 \%$ of melanomas $(6,7)$. Viros and colleagues showed that induction of TP53 mutation, or its inactivation, accelerate BRAF-driven melanogenesis (6). Functional p53 protein is a major regulator of cell cycle arrest during sun-damaged DNA repair or p53 induced apoptosis $(6,7)$. Conventional chemotherapy usually targets p53 function, but melanomas are resistant to 553 dependent apoptosis, which might be a reason for melanoma resistance to chemotherapy (8). According to Terzian et al. increased p53 can prevent progression of nevi to melanoma and specific activation of p53 might be an effective strategy to reduce the risk of melanoma (7).

BRAF mutation is one of the early events in malignant transformation of melanocytes. Still, it is considered that single mutation is not sufficient 
to induce melanoma, since BRAFV600 mutations are frequently found in benign and dysplastic melanocytic nevi (9). Thus, the NCCN Clinical Practice Guidelines in Oncology (2017) do not recommend the BRAF mutation testing of primary cutaneous melanoma, unless required for systemic therapy (2). UV-induced mutations, as loss of function in tumor suppressor gene phosphatase and tensin homolog, PTEN (found in $40-60 \%$ of melanomas), mutations in cyclin-dependent kinase inhibitor 2A (CDKN2A) (found in $\sim 40 \%$ of melanomas) and over-expression of MDM4 protein (found in $~ 60 \%$ of melanomas), both acting as a negative regulator of $\mathrm{p} 53$ protein, were also described $(1,3,4)$.

\section{BRAF mutations}

The BRAF gene encodes a protein which plays a role in the control of cell proliferation, differentiation, inflammatory responses and apoptosis via the mitogen activated protein kinase (MAPK) pathway (10). Mutations of BRAF gene have been found in $\sim 60 \%$ of all $\mathrm{MM}$ and the most prevalent mutations are located on codon 600 of the BRAF gene. The most common BRAFV600E mutation is the result of a transversion of thymine to adenine at nucleotide 1799 (T1799A), and subsequently a substitution of valine $(\mathrm{V})$ for glutamic acid (E) in position 600 of BRAF protein. Less common substitutions are of $\mathrm{V}$ for lysine (V600K $(\sim 8-$ $20 \%)$ ), arginine (V600R (1\%)), leucine (V600M $(0.3 \%))$, and aspartic acid (V600D (0.1\%)). Some nonV600 mutations (K601E, D594N) are also found in a low percentage of patients, but till today without known clinical significance. RAF mutation results in constitutive activation of the MAPK signaling pathway $(10,11)$.

Patients with the detected BRAFV600 mutation are candidates for the BRAF inhibitor therapy with vemurafenib and dabrafenib, that become an important step forward in the treatment of melanomas $(9,12)$. Although BRAF inhibitor therapy is associated with clinical benefit, the majority of patients with the BRAFV600 mutated MM develop resistance to vemurafenib, usually within the first year. Mechanisms of resistance to the BRAF inhibitors might be acquired by amplification or mutations in other genes evolved in the same pathways. Amplification of BRAF, CRAF, insulinlike growth factor 1 receptor (IGF1R), hepatocyte growth factor (HGF), and platelet-derived growth factor receptor (PDGFR $\beta$ ), and mutations in NRAS, MEK1, NF1 and PI3KCA genes were detected. As Shi and colleagues reported, $70 \%$ of the resistance is acquired through the MAPK reactivation. NRAS mutations were detected in $18 \%$, KRAS in $7 \%$ and BRAF amplification or alternative splicing were detected in more than $40 \%$ of melanoma resistant to BRAF inhibitors (12).

The majority of tumors are heterogeneous, which has recently been confirmed in melanomas. The molecular profile of MM can change over time, and the amount of mutations increase with progression (13). Furthermore, some mutually exclusive mutations (eg. BRAF and NRAS) can be present in the same tumor due to its clonal heterogeneity $(13,14)$. Recently, discrepancy in BRAF mutation between primary melanoma and metastases and between different metastatic sites of recurrent melanoma has been documented. Yancovitz et al. detected discordant BRAF status among two metastases of the same patients in $26 \%$ and between primary melanoma and a metastasis in $33 \%$ (15). Heinzerling analyzed up to 13 tumour samples per patient and found discordant results in $18.9 \%$ of patients while discordance between primary tumours and metastases was detected in $44 \%$ of patients (16). Yet, Hannah et al. found discordance between primary melanoma and brain metastasis in only $14 \%$ of cases (17). Meta-analysis performed by Valachis and Ullenhag detected discrepancy in BRAF status between primary and metastatic lesions in $13.4 \%$ and between two metastatic lesions in $7.3 \%$ of cases (18). Meta-analysis by Grzywa and colleagues found overall heterogeneity in $8.1 \%$ of melanomas and $16 \%$ heterogeneity in BRAF-mutated melanomas. They also recorded discrepancy in BRAF status between primary and metastatic lesions in $15.5 \%$ of cases (19). Melanomas heterogeneity still remains controversial and Riveiro-Falkenbach suggested that inconsistency between primary and metastatic melanomas can be a result of different molecular tests or quality of samples used for BRAF detection (20).

\section{Other driver mutations}

MEK1 (MAP2K1) is a central mediator in the MAPK signaling pathway. Somatic mutations in MEK1 have been found in $6-7 \%$ of MM and often occur together with BRAF or NRAS mutations. 
The MEK inhibitor therapy (trametinib and cobimetinib) is used for the treatment of BRAFV600Emutated melanoma resistant to BRAF inhibitors. Mutations in NRAS have been found in 13-25\% of all MM with the result of constitutive activation of the MAPK pathway. Our pilot study detected NRAS mutations in over $60 \%$ of BRAF wild type metastatic melanomas (not published), namely a substitution of glutamine to arginine/lysine/leucine at position $61(\mathrm{Q} 61 \mathrm{R} / \mathrm{K} / \mathrm{L})$. NRAS mutations might respond to MEK inhibitor-based therapy $(1,3,10,11)$.

Mutations in G proteins (GNA11 and GNAQ) have been found in up to $2.3 \%$ of all MM. Expression of $G$ proteins results in melanocyte transformation and increased signaling through the MAPK pathway $(1,3,10,11)$.

Neurofibromin 1 (NF1) is a tumor suppressor gene that suppresses the function of the RAS protein. NF1 mutations occur in $11.9 \%$ of MM. Inactivation or loss of NF1 function might play a role in melanomagenesis. NF1 mutations might be responsible for resistance to RAF/MEK targeted therapies. Currently, there is no therapy directed to G-proteins or NF1 $(1,3,10,11)$.

C-KIT (CD117) is a receptor tyrosine kinase that activates the PI3K pathway, the MAPK pathway, and other pathways involved in mediating pro-growth and pro-survival signaling. Mutations or amplification of KIT gene has been founded in 3-9\% of all MM. Phase II clinical trials have demonstrated clinical responses of c-KIT-mutated melanoma to imatinib, sunitinib, sorafenib, and nilotinib, and everolimus after acquiring resistance to imatinib $(1,3,10,11)$.

The CTNNB1 gene encodes the $ß$-catenin that regulates cell growth and adhesion of epithelial cells regulated via glycogen synthase kinase 3 beta (GSK3 3 ). Somatic mutations in CTNNB1 have been found in $2-7 \%$ of MM. Concurrent mutations in $ß$-catenin and NRAS act synergistic in promoting melanoma formation $(1,3,10,11)$.

Several other amplifications (MITF, MYC, AKT3), and mutations in genes (AT-rich interactive domain-containing protein 2 (ARID2), protein phosphatase 6 (PPP6C), sorting nexin 31 (SNX31), rac family small GTPase 1 (RAC1); serine/threonine kinase 19 (STK19), and transforming acidic coiled-coil-containing protein 1 (TACC1)) were discovered recently, that might be a potential target in melanoma therapy $(1,3,10,11)$.

\section{CONCLUSION}

Clinically significant discrepancy in BRAF status, between primary melanoma and its metastasis, is reported in about $15 \%$ of cases. There are no specific recommendations about BRAF retesting, although repeating testing on recent metastatic sites might be clinically relevant, especially in cases of previous BRAF wild type results. Despite the fact that changes in melanoma cells occur during progression, there is no additional testing recommendations till today. Recent literature, discovered many potential targets for developing a specific therapy, of which we presented the most promising one.

\section{REFERENCES}

1. D'Orazio JA, Jarrett S, Marsch A, Lagrew J, Cleary L. Melanoma - epidemiology, genetics and risk factors. In: Davids LM, ed. Recent advances in the biology, therapy and management of melanoma. InTech. [Published online Feb 13, 2013]. Available at: http://www. intechopen.com/books/recent-advances-in-thebiology-therapy-and-management-of-melanoma. Accessed on Marth $9^{\text {th }} 2018$.

2. National Comprehensive Cancer Network (NCCN). Practice guidelines in Oncology: Melanoma version 1, Available at: https://www.nccn.org/professionals/ physician_gls/pdf/melanoma.pdf . Accessed on Marth $9^{\text {th }} 2018$.

3. Lo JA, Fisher DE. The melanoma revolution: from UV carcinogenesis to a new era in therapeutics. Science. 2014;346(6212):945-9.

4. Lin JY, Fisher DE. Melanocyte biology and skin pigmentation. Nature. 2007;445:843-50.

5. D'Mello SA, Finlay GJ, Baguley BC, Askarian-Amiri ME. Signaling pathways in melanogenesis. Int J Mol Sci. 2016;17(7):1144. doi: 10.3390/ijms17071144.

6. Viros A, Sanchez-Laorden B, Pedersen M, Furney SJ, Rae J, Hogan $\mathrm{K}$ et al. Ultraviolet radiation accelerates BRAF-driven melanomagenesis by targeting TP53. Nature. 2014;511(7510):478-82.

7. Terzian T, Torchia EC, Dai D, Robinson SE, Murao K, Stiegmann RA et al. p53 prevents progression of nevi to melanoma predominantly through cell cycle regulation. Pigment Cell Melanoma Res. 2010; 23(6):781-94.

8. Box NF, Vukmer TO, Terzian T. Targeting p53 in melanoma. Pigment Cell Melanoma Res. 2014;27(1):8-10.

9. Cheng L, Lopez-Beltran A, Massari F, MacLennan GT, Montironi R. Molecular testing for BRAF mutations to inform melanoma treatment decisions: a move toward precision medicine. Modern Pathol. 2018;31:24-38.

10. Lovly C, Pao W, Sosman J. Molecular Profiling of Melanoma. My cancer genome. Available at: https://www. 
mycancergenome.org/content/disease/melanoma/ (Updated 26 Jan, 2016). Accessed on Marth $9^{\text {th }} 2018$.

11. Hodis E, Watson IR, Kryukov GV, Arold ST, Imielinski $\mathrm{M}$, Theurillat JP et al. A landscape of driver mutations in melanoma. Cell. 2012;150:251-63.

12. Shi H, Hugo W, Kong X, Hong A, Koya RC, Moriceau $G$ et al. Acquired resistance and clonal evolution in melanoma during BRAF inhibitor therapy. Cancer Discov. 2014;4:80-93.

13. Shain AH, Yeh I, Kovalyshyn I. The genetic evolution of melanoma from precursor lesions. N Engl J Med 2015;373:1926-36.

14. Chang GA, Polsky D. Mutational heterogeneity in melanoma: An inconvenient truth. J Invest Dermat. 2015;135:2913-18.

15. Yancovitz M, Litterman A, Yoon J, Ng E, Shapiro RL, Berman RS et al. Intra- and inter-tumor heterogeneity of BRAF(V600E) mutations in primary and metastatic melanoma. PloS One. 2012;7:e29336. doi: 10.1371

16. Heinzerling L, Baiter M, Kühnapfel S, Schuler G, Keikavoussi P, Agaimy A et al. Mutation landscape in melanoma patients clinical implications of heterogeneity of BRAF mutations. Br J Cancer 2013;109:2833-41.

17. Hannan EJ, O'Leary DP, MacNally SP, Kay EW, Farell MA, Morris PG et al. The significance of BRAF V600E mutation status discordance between primary cutane- ous melanoma and brain metastases The implications for BRAF inhibitor therapy. Medicine (Baltimore) 2017;96(48):e8404. doi: 10.1097/MD.0000000000008404.

18. Valachis A, Ullenhag GJ. Discrepancy in BRAF status among patients with metastatic malignant melanoma: A meta-analysis. Eur J Cancer. 2017;81:106-15.

19. Grzywa TM, Paskal W, Włodarski PK. Intratumor and intertumor heterogeneity in melanoma.Transl Oncol. 2017;10:956-75.

20. Riveiro-Falkenbach E, Villanueva CA, Garrido MC, Ruano Y, García-Martín RM, Godoy E et al. Intra- and inter-tumoral homogeneity of BRAFV600E mutations in melanoma tumors. J Invest Dermatol 2015;135(12):3078-85. doi: 10.1038/jid.2015.229.

21. Eriksson H, Zebary A, Vassilaki I et al. BRAFV600E protein expression in primary cutaneous malignant melanomas and paired metastases. JAMA Dermatol. 2015;151:410-6.

Corresponding author: Snježana Ramić, Department of Oncological Pathology, 'Ljudevit Jurak' University Department of Pathology, Sestre milosrdnice University Hospital Center, Ilica 197, Zagreb, Croatia. email:snjezana.ramic@zg.t-com.hr 